\title{
Lignin-Based Additives for Improved Thermo-Oxidative Stability of Biolubricants
}

\author{
Monika A. Jedrzejczyk, Sander Van den Bosch, Joost Van Aelst, Korneel Van Aelst, Panos D. Kouris, \\ Mohamed Moalin, Guido R. M. M. Haenen, Michael D. Boot, Emiel J. M. Hensen, Bert Lagrain, \\ Bert F. Sels, and Katrien V. Bernaerts*
}

Cite This: ACS Sustainable Chem. Eng. 2021, 9, 12548-12559

Read Online

ACCESS | 네 Metrics \& More | 回 Article Recommendations | sl Supporting Information

ABSTRACT: There is an environmental concern regarding the use of petroleum-based lubricants, which are generally toxic and nonbiodegradable. Biobased lubricants, such as vegetable oils, are the alternative: they show excellent lubricity, are readily biodegradable and nontoxic. However, a major disadvantage of using vegetable oils in lubricant applications is their lack of thermooxidative stability, which can be improved by antioxidant additives. Here, we propose the use of lignin-based additives in biolubricant formulations to improve this feature, based on lignin's known antioxidant properties. To ensure a stable dispersion in vegetable oil, lignin was partially esterified. Antioxidant properties of lignin before and after palmitoylation were demonstrated in a 2,2-

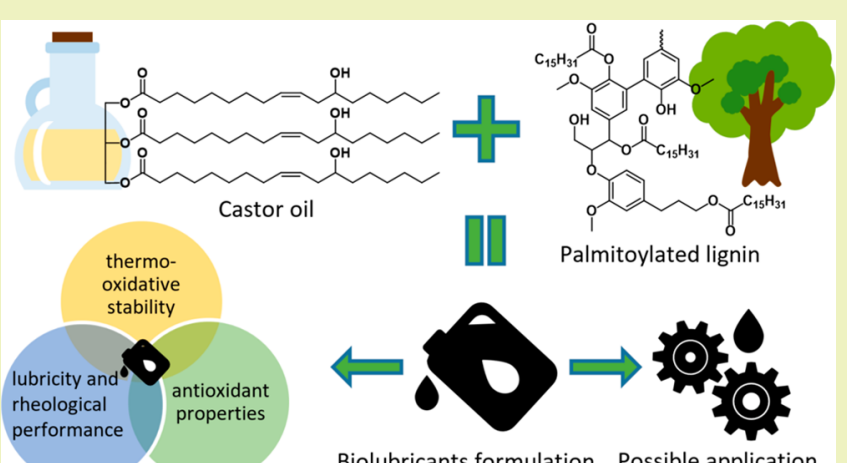

Biolubricants formulation Possible application diphenyl-1-picrylhydrazyl (DPPH) assay. Four different ligninbased fractions, commercial Protobind P1000 soda lignin from straw, solvolytically fractionated Protobind P1000 lignin and two lignin fractions from reductively catalyzed fractionation (RCF) of native birch wood, were tested in biolubricant formulations with castor oil as base oil. Those lignin fractions exhibited excellent performance compared to butylated hydroxytoluene (BHT), a commonly used petroleum-based antioxidant. Formulations of modified lignin in castor oil possess improved thermo-oxidative stability, as illustrated by their increased oxidation induction time. Additionally, rheological and tribological tests demonstrate similar, or in some cases improved, lubricating properties compared to castor oil. This study showcases the successful incorporation of lignin-based antioxidants in biolubricant formulations, tackling the major disadvantage of vegetable oils as environment-friendly lubricants.

KEYWORDS: Lignin, Esterified lignin, Biolubricants, Antioxidants, DPPH assay, Thermo-oxidative stability, Tribology, Rheology, Biorefinery

\section{INTRODUCTION}

The main purpose of lubricants is to protect moving parts in, for example, engines and machinery by reducing heat, friction, and wear when they are in motion. There is a constant growth in the use of lubricants, which are primarily used by the automotive industry, and the estimated global market size is $30-40$ million tons annually. ${ }^{1}$ About $90-95 \%$ of lubricants are petroleum-based products. ${ }^{2}$ Approximately half of these products end up in the environment, due to total-loss applications, spillage, evaporation, and mishandling, polluting soil, water, and air as a result of their toxicity and lack of biodegradability.

An environment-friendly alternative to synthetic petroleumbased lubricants are biolubricants such as vegetable oils. Promising oils for this application include sunflower, rapeseed, soybean, castor, jatropha, and neem oils among others. ${ }^{1,3}$ Next to their biodegradability, renewable, and nontoxic character, vegetable oils possess advantageous performance features: excellent lubricity, low volatility, high flash point, and viscosity. ${ }^{2,4}$ Nonetheless, their biggest drawback is limited thermo-oxidative and hydrolytic stability, which can be overcome by the use of additives or chemical modification of the oil by transesterification, epoxidation, estolide formation, or hydrogenation. ${ }^{1,2,4}$

In our view, the focus should be pointed toward biolubricants originating from nonedible vegetable oils, to avoid competition with feed and food resources. Castor oil is a good example of such an oil. It is mostly composed of the

Received: April 26, 2021

Revised: August 27, 2021

Published: September 9, 2021 
triglyceride of ricinoleic acid (Figure 1). Hydroxyl groups present in its structure lead to increased polarity and provide it

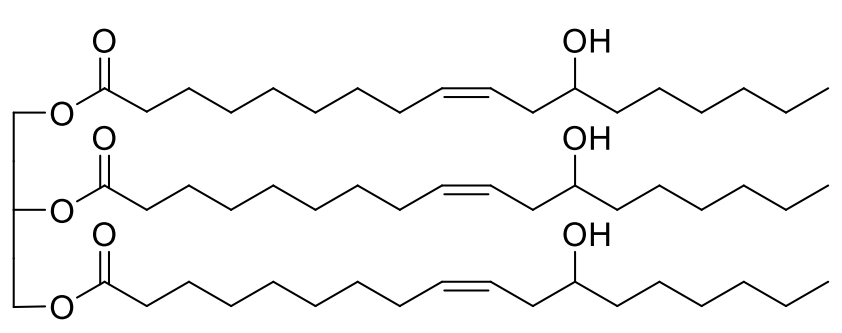

Figure 1. Chemical structure of the triglyceride of ricinoleic acid, which is the main triglyceride in castor oil.

with improved properties, such as enhanced lubricity, affinity to metals, increased viscosity, better low-temperature performance, and a generally higher additive solubility compared to other vegetable oils. ${ }^{5}$ Such features make castor oil a preferred base oil for lubricant formulations. ${ }^{6}$ Castor oil finds applications in various fields including lubricants, fuels, paints, coatings, polymer synthesis, fertilizers, and pharmaceuticals. ${ }^{7,8}$

Low oxidation stability is one of the major obstacles hampering industrial acceptance of vegetable oil-based lubricants. ${ }^{9,3}$ In this work, the activity of natural antioxidants, like lignin and its derivatives, in vegetable oil-based lubricants was evaluated. Lignin is the most abundant polyphenolic material on earth and present in land-based biomass. It is biosynthesized by cross-linking of monolignols (syringyl $(S)$, guaiacyl (G), and p-hydroxyphenyl (H) units, Figure 2). ${ }^{9}$ Next

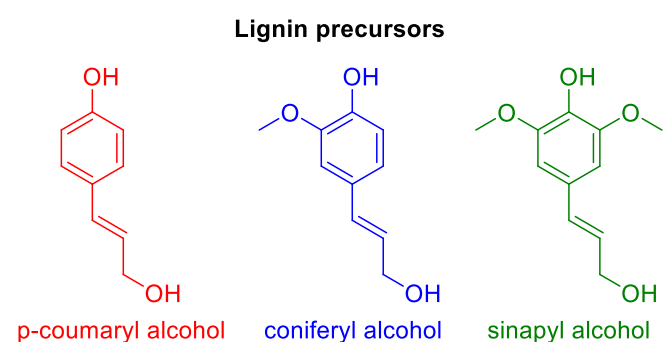

Structural units in lignin

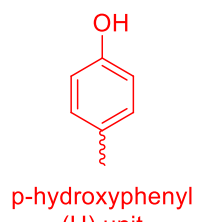

(H) unit

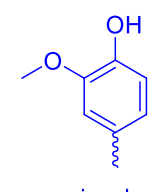

guaiacyl

(G) unit

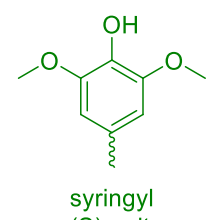

(S) unit
Figure 2. Lignin building blocks and structural units.

to the antioxidant properties of lignin and lignin-derived products, also enhanced antimicrobial and antifungal activity against certain species has been indicated for lignin., ${ }^{9,10}$ Moreover, lignin is already proven to have low toxicity and to be biocompatible under certain circumstances. ${ }^{9,10}$ Lignin fractions can be produced by various isolation, fractionation, and depolymerization approaches, as for instance reviewed by Liu et al. and Chio et al. ${ }^{112}$ Lignin products have been valorized as components in polymeric materials, adhesives, coatings, fuels, antioxidants, additives, and platform chemicals among others. ${ }^{9,13-15}$
It has been reported that lignin can be incorporated into various biolubricant formulations. Gallego et al., Acar et al., and Borrero-López et al. demonstrated that lignin derivatives (hexamethylene diisocyanate cross-linked, epoxide, or isocyanate functionalized lignin) act as thickening agents in castor and sunflower oils. ${ }^{16-18}$ Delgado et al. showed that epoxidized lignin can be used as a thickener in castor oil biogreases exhibiting improved tribological and antiwear performance. ${ }^{19}$ Hua et al. and $\mathrm{Mu}$ et al. investigated the effect of lignin on thermal and tribological properties of ionic liquid based biolubricants. ${ }^{20,21} \mathrm{Mu}$ et al. also studied the influence of lignin in ethylene glycol and polyethylene glycol (PEG) matrices on lubricating performance. ${ }^{22}$ Cortés-Triviño et al. showed that epoxidized lignin can be used as a rheology modifier in castoroil-based gel-like dispersions. ${ }^{23}$ Unfortunately, the thermooxidative stability of those formulations was not investigated.

Chandrasekaran et al. reported the use of phenolic bio-oils, obtained after slow pyrolysis of birchwood and Kraft lignin, as an antioxidant additive in soy biodiesel. ${ }^{24}$ In that research, the bio-oil was a mixture of phenolic monomers and dimers, and this mixture exhibited slightly better antioxidant activity than BHT in soybean oil, while physical properties were not affected by the additive. ${ }^{24}$ This study was followed up by Larson et al., who showed that bio-oil from softwood lignin pyrolysis exhibits antioxidant properties similar to those of BHT in soybean methyl ester biodiesel. ${ }^{25}$ In that work the authors recognized dimeric phenolic compounds as the most potent antioxidants in the pyrolisate, while monomeric phenolic compounds were less active. Dimers were more active as their double functionality enables separate hydrogen bonding and radical quenching, while monomeric phenols predominantly interact with oils via hydrogen bonding, which reduces their activity. Cesari et al. evaluated the antioxidant activity of the model phenolic compounds which could be obtained after lignin depolymerization and showed that all of them exhibit antioxidant performance in multiple antioxidant property assays. $^{26}$ Similarly, Quinchia et al. showed that natural antioxidants such as $(+)-\alpha$-tocopherol, propyl gallate, or ascorbyl palmitate can be used in biolubricant formulations, improving the oxidative stability of the high-oleic sunflower and castor oils. ${ }^{27}$ The main difference between those works and this study is that we evaluate the performance of ligninbased oligomeric fractions as well, not only phenolic monomers and dimers. Polymeric lignin has been proven by Kaur and Uppal to possess radical scavenging activity, and Kasprzycka-Guttman and Odzeniak have shown that it can inhibit auto-oxidation of arachide nut oil; in both studies the lignin performance was slightly better than that with BHT. ${ }^{28,29}$

Here, we propose an alternative approach toward the development of lignin-containing biolubricants, by improving their main disadvantage, i.e., suboptimal thermo-oxidative stability. To improve this property, we apply lignin-based antioxidant additives, which were modified by palmitoylation to increase their lipophilicity. In this research, we investigated several lignin types to derive structure-property-function relationships, i.e., (i) commercial Protobind P1000 soda lignin from straw, (ii) solvolytically fractionated Protobind P1000 lignin from straw, ${ }^{30}$ and (iii) lignin fractions from reductively catalyzed fractionation (RCF) of native birch wood. ${ }^{31-33}$ P1000 lignin was selected as a representative sample of commercially available lignins and because it is a starting material for the solvolysis of the lignin fraction used in this study. As a source of biomass for RCF, birch wood was 
selected since it is a significant wood source in the Scandinavian region, and it is a good benchmark often used in RCF literature. ${ }^{15}$ These fractions were selected due to ongoing scale up initiatives and coming commercialization of these types of lignin, and their application development is required. ${ }^{34,35}$ Our goal is to assess the potential of palmitoylated lignin as an antioxidant additive in castor oil formulations to improve thermo-oxidative stability, while maintaining the required rheological and tribological performance.

\section{EXPERIMENTAL SECTION}

Please refer to the SI for the materials section.

Methods. P1000 lignin solvolysis: the $\mathrm{CLO} \mathrm{MeOH}$ fraction was obtained from P1000 lignin (wheat straw soda lignin), by solvolysis in $\mathrm{MeOH}$ under mild conditions. ${ }^{30,36} \mathrm{~A}$ total of $300 \mathrm{~g}$ of P1000 lignin was loaded in a $4 \mathrm{~L}$ batch reactor (Parr Instruments \& Co.) and mixed with $1500 \mathrm{~mL}$ of $\mathrm{MeOH}$ [1:5 w/v]; the solvolysis was carried out at $200{ }^{\circ} \mathrm{C}$ with 10 bar of nitrogen gas for $30 \mathrm{~min}$. After the reaction, the reaction mixture was filtered, and the solvent was removed by rotary evaporation $\left(45-50{ }^{\circ} \mathrm{C}, 5 \mathrm{mbar}\right)$ for $1 \mathrm{~h}$. The final oligomeric fractions were dried at $80{ }^{\circ} \mathrm{C}$ until a stable weight was achieved.

Reductive Catalytic Fractionation (RCF): The depolymerized lignin fractions, namely $\mathrm{Ru} / \mathrm{C}$ and $\mathrm{Pd} / \mathrm{C}$ hexane residues, were obtained by RCF of lignocellulose biomass. ${ }^{31-33}$ The RCF experiment was performed in a $2 \mathrm{~L}$ stainless steel batch reactor (Parr Instruments \& Co.). A total of $150 \mathrm{~g}$ of birch wood chips, milled with a Retsch cutting mill with a $2 \mathrm{~mm}$ screen, was loaded into the reactor, together with $15.0 \mathrm{~g}$ of $\mathrm{Pd} / \mathrm{C}$ or $15.0 \mathrm{~g}$ of $\mathrm{Ru} / \mathrm{C}$ and $800 \mathrm{~mL}$ of methanol. Subsequently, the reactor was sealed, flushed three times with nitrogen gas (10 bar), and then pressurized with hydrogen gas (30 bar at room temperature). Next, the reaction mixture was stirred (750 rpm) and simultaneously heated to $235{ }^{\circ} \mathrm{C}(\sim 30 \mathrm{~min}$ heating time). After the reaction time of $3 \mathrm{~h}$, the reactor was cooled and depressurized at room temperature. The reactor contents were quantitatively collected by washing the reactor with ethanol. The solid pulp was separated by filtration and washed thoroughly with ethanol. Next, the standard protocol for the separation of carbohydrates, monomers, and lignin oligomers was applied. ${ }^{37}$ The resulting filtrate was evaporated, and a brown oil was obtained, which was solubilized in dichloromethane (DCM) and subjected to liquid-liquid extractions using DCM and water: per 1 equiv of DCM, 4 equiv of water was used; after the DCM fraction was separated and the aqueous fraction was extracted with fresh DCM three times in total. To obtain the RCF lignin oil, the combined DCM-extracted phases were evaporated and dried in an oven of $80^{\circ} \mathrm{C}$. This RCF lignin oil (1 g equivalent) was 4 -fold extracted with a mixture of hexane $(3 \mathrm{~mL}$ equivalent) and water $(3 \mathrm{~mL}$ equivalent $)$ for $30 \mathrm{~min}$ at $80^{\circ} \mathrm{C} .{ }^{37}$ After each extraction, the soluble hexane phase was removed, and fresh hexane was added. The residue after the four hexane extractions was obtained by rotavap evaporation of water and drying in a vacuum oven. All lignin fractions, $\mathrm{P} 1000$ lignin, $\mathrm{CLO} \mathrm{MeOH}$, and $\mathrm{Ru} / \mathrm{C}$ and $\mathrm{Pd} / \mathrm{C}$ hexane residues, were vacuum-dried $\left(80{ }^{\circ} \mathrm{C}, 5-10 \mathrm{mbar}\right.$, overnight) prior to use and analysis.

All lignin fractions were partially modified with palmitoyl chloride (Scheme 1) in order to make them compatible with the biolubricants matrix (castor oil) while maintaining their antioxidant properties. The general procedure was as follows: $1.0 \mathrm{~g}$ of lignin sample was dissolved in $40 \mathrm{~mL}$ of dry dichloromethane and stirred under a nitrogen atmosphere. Next, 0.5 equiv* (based on the total phenolic and aliphatic $\mathrm{OH}$ content per lignin source; $* 0.4$ equiv was used for $\mathrm{Pd} / \mathrm{C}$ hexane residue sample) of dry pyridine was added to the reaction mixture, followed by the addition of equimolar equivalents of palmitoyl chloride. The reaction was carried out under a nitrogen atmosphere at room temperature for $24 \mathrm{~h}$. Afterward, the reaction mixture was washed with $40 \mathrm{~mL}$ of $10 \%$ hydrochloric acid and brine $(3 \times 40 \mathrm{~mL})$. The product was dried in a vacuum before analysis by
Scheme 1. Lignin Esterification Reaction Scheme

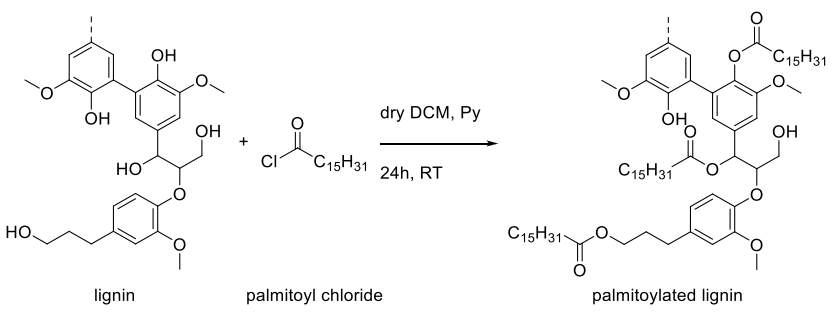

GC (SI, Table S1) and ${ }^{31} \mathrm{P}$ nuclear magnetic resonance (NMR) spectroscopy (Table 2). Fully modified P1000 lignin was prepared using the same procedure, but 1.5 equiv of palmitoyl chloride was used.

Esterified lignin was dispersed in castor oil by adding the appropriate amount of components at room temperature, and subsequently they were sonicated using a Branson 3800 Ultrasonic bath at $70{ }^{\circ} \mathrm{C}$ for $1 \mathrm{~h}$. The concentrations of lignin fractions were adjusted to have the same free phenolic $\mathrm{OH}$ content originating from the lignin fraction per $1 \mathrm{~g}$ of castor oil. The concentrations were $0.007,0.034$, and $0.071 \mathrm{mmol} \mathrm{OH} / \mathrm{g}$ castor oil; the weight percentage corresponding to this can be found in Table S1.

Characterization. The aromatic and aliphatic hydroxyl groups as well as the carboxylic acids (before and after modification) of lignin were determined by ${ }^{31} \mathrm{P}$ NMR spectroscopy after sample derivatization, according to the method described by Korntner et al. ${ }^{38} \mathrm{~A}$ total of $10 \mathrm{mg}$ of dried (in a vacuum oven at $80{ }^{\circ} \mathrm{C}$, overnight), lignin-based material was dissolved in $500 \mu \mathrm{L}$ of anhydrous pyridine and deuterated chloroform mixture (1.6:1, v:v). Then, $100 \mu \mathrm{L}$ of internal standard solution, cholesterol $(19.7 \mathrm{mg} / \mathrm{mL}$ in anhydrous pyridine and deuterated chloroform mixture, $1.6 / 1, \mathrm{v} / \mathrm{v}, 0.0051 \mathrm{mmol}$ ), $50 \mu \mathrm{L}$ of relaxation agent, chromium(III) acetylacetonate $(10 \mathrm{mg} / \mathrm{mL}$, in anhydrous pyridine and deuterated chloroform mixture, 1.6:1, v-v), and $50 \mu \mathrm{L}$ of derivatizing agent, 2-chloro-4,4,5,5-tetramethyl-1,3,2dioxaphospholane, were added to the solution. The solution was stirred for $10 \mathrm{~min}$, transferred into a dry $5 \mathrm{~mm} \mathrm{NMR}$ tube, and measured. The measurement was performed on a Bruker Avance III HD Nanobay $300 \mathrm{MHz}$ apparatus (121.49 $\mathrm{MHz}$ for ${ }^{31} \mathrm{P}$ NMR experiments) using the standard phosphorus pulse program, at ambient temperature, with 256 scans, a relaxation delay of $5 \mathrm{~s}$, an acquisition time of $2 \mathrm{~s}$, a transmitter excitation frequency of $140 \mathrm{ppm}$, and a spectral width of $396 \mathrm{ppm}$. The chemical shifts were reported in ppm. Chemical shifts were referenced from the sharp signal of the reaction product between residual water and 2-chloro-4,4,5,5tetramethyl-1,3,2-dioxaphospholane at $132.2 \mathrm{ppm}$. The signals were assigned as follows: $144.8 \mathrm{ppm}$, cholesterol $\mathrm{OH}$ group (internal standard); 133.8-135.5 ppm, carboxyl groups; 137-138.5 ppm, hydroxyphenyl units; $138.5-140.4$ ppm, guaiacyl units; 140.4-144.8 ppm, syringyl and condensed guaiacyl units; $145-151$ ppm, aliphatic hydroxyl groups. ${ }^{38}$ The quantification of the hydroxyl groups was performed according the protocol described in the literature. ${ }^{39}$

The molecular weight distribution of lignin was obtained from gel permeation chromatography (GPC) analysis. It was performed at 30 ${ }^{\circ} \mathrm{C}$ using a Waters GPC equipped with a Waters 2414 refractive index detector. Tetrahydrofuran was used as an eluent at a flow rate of 1 $\mathrm{mL} / \mathrm{min}$. Three linear columns were used (Styragel HR1, Styragel HR4, and Styragel HR5). Lignin samples were acetylated by acetic anhydride in the presence of pyridine before the measurement using the protocol described by Gosselink et al..$^{40}$ Acetylated lignin samples (approximately $7 \mathrm{mg}$ ) were dissolved in $1.5 \mathrm{~mL}$ of tetrahydrofuran, and samples were filtered with a PTFE syringe filter (pore size 0.2 $\mu \mathrm{m})$ prior to measurement. Molecular weights were given relative to polystyrene standards within the calibration range of 370-2 520000 Da.

Samples before and after palmitoylation were measured by gas chromatography (GC) to determine the monomer content in the lignin fractions using the procedure described by Van Aelst et al. ${ }^{33}$ Therefore, a weighed amount of external standard (2-isopropylphe- 
Table 1. Characterization of Lignin-Based Fractions by ${ }^{31} \mathrm{P}$ NMR Spectroscopy and GPC

\begin{tabular}{|c|c|c|c|c|c|c|c|c|}
\hline sample & source & $\begin{array}{c}\text { phenolic OH } \\
{[\mathrm{mmol} / \mathrm{g}]}\end{array}$ & $\underset{[\mathrm{mmol} / \mathrm{g}]}{\operatorname{aliphatic~OH}}$ & $\begin{array}{c}\mathrm{COOH} \\
{[\mathrm{mmol} / \mathrm{g}]}\end{array}$ & $\begin{array}{c}\text { phenolic } \mathrm{OH} \text { of }(\mathrm{S}+\mathrm{G}) / \mathrm{H} \\
\text { type ratio }{ }^{a}[\%]\end{array}$ & $\begin{array}{c}M_{\mathrm{w}}{ }^{b} \\
{[\mathrm{kDa}]}\end{array}$ & $\begin{array}{c}M_{\mathrm{n}}^{b} \\
{[\mathrm{kDa}]}\end{array}$ & $\begin{array}{c}\boxplus^{b}\left[M_{\mathrm{w}} /\right. \\
\left.M_{\mathrm{n}}\right]\end{array}$ \\
\hline $\begin{array}{l}\mathrm{Ru} / \mathrm{C} \text { hexane } \\
\text { residue }\end{array}$ & $\begin{array}{l}\text { birch wood } \\
\quad(\text { hardwood })^{c}\end{array}$ & 3.47 & 2.70 & 0.09 & $96 / 4$ & 1.7 & 0.7 & 2.6 \\
\hline $\begin{array}{l}\mathrm{Pd} / \mathrm{C} \text { hexane } \\
\text { residue }\end{array}$ & $\begin{array}{l}\text { birch wood } \\
\quad(\text { hardwood })^{d}\end{array}$ & 3.43 & 4.33 & 0.12 & $98 / 2$ & 0.8 & 0.6 & 1.4 \\
\hline $\mathrm{CLO} \mathrm{MeOH}$ & $\begin{array}{l}\text { P1000 lignin (wheat } \\
\text { straw) }\end{array}$ & 3.22 & 1.27 & 0.35 & $85 / 15$ & 2.3 & 1.1 & 2.1 \\
\hline P1000 lignin & wheat straw ${ }^{f}$ & 3.71 & 1.80 & 0.95 & $85 / 15$ & 4.3 & 1.9 & 2.6 \\
\hline
\end{tabular}

nol; $\sim 20 \mathrm{mg}$ ) was added to a GC vial containing a weighed amount of lignin $(\sim 40 \mathrm{mg})$. Subsequently $0.3 \mathrm{~mL}$ of pyridine and $0.3 \mathrm{~mL}$ of $\mathrm{N}$ methyl-N-(trimethylsilyl)trifluoroacetamide were added, next to 0.6 $\mathrm{mL}$ of acetonitrile. The vial was sealed and put in an oven at $80{ }^{\circ} \mathrm{C}$ for $30 \mathrm{~min}$. Afterward, the samples were analyzed on a gas chromatograph (Agilent 6890 series) equipped with an HP5 column and a flame ionization detector (FID). The following operating conditions were used: injection temperature of $300{ }^{\circ} \mathrm{C}$, column temperature program $=50{ }^{\circ} \mathrm{C}(2 \mathrm{~min}), 15{ }^{\circ} \mathrm{C} / \mathrm{min}$ to $150{ }^{\circ} \mathrm{C}, 10{ }^{\circ} \mathrm{C} / \mathrm{min}$ to 220 , and 20 ${ }^{\circ} \mathrm{C} / \mathrm{min}$ to $290{ }^{\circ} \mathrm{C}(12 \mathrm{~min})$, with a detection temperature of $300{ }^{\circ} \mathrm{C}$. Sensitivity factors of the products are obtained by calibration with commercial standards or estimated, based on effective carbon number (ECN) calculations or trends within the response factors (RFs) of commercial standards.

DPPH free radical scavenging assays of all modified and unmodified lignins were performed using the procedure described by de Menezes et al. ${ }^{41}$ Lignin and BHT solutions were prepared at the same molar concentration $(0.005 \mathrm{mmol} / \mathrm{mL}$, the equivalent of $1 \mathrm{mg} /$ $\mathrm{mL}$ of BHT, based on phenolic OH content) in a $90 \%(\mathrm{v} / \mathrm{v}) 1,4-$ dioxane-water solution. A DPPH radical working solution in $90 \%$ (v/ v) 1,4-dioxane-water of $0.04 \mathrm{mg} / \mathrm{mL}$ was prepared from a $10 \mathrm{mg} / \mathrm{mL}$ stock solution. To $1350 \mu \mathrm{L}$ of the DPPH radical working solution, the lignin solution was added $(10,30,75,150$, or $300 \mu \mathrm{L})$ to start a reaction, and subsequently a mixture of $90 \%(\mathrm{v} / \mathrm{v})$ of 4-dioxane in water was added to a total volume of $3 \mathrm{~mL}$ with a $90 \%(\mathrm{v} / \mathrm{v}) 1,4-$ dioxane-water solution. The reaction mixture was mixed and kept in the dark for $30 \mathrm{~min}$ after starting the reaction before the absorption of light of $\lambda=520 \mathrm{~nm}$ was determined, using a Jasco V-650 spectrometer. The reduction in absorption reflects the amount of DPPH radicals that have been scavenged by the antioxidant compound. The antioxidant activity is expressed as $\mathrm{IC}_{50}$ values in $\mu \mathrm{mol} / \mathrm{mL}$ or $\mu \mathrm{g} / \mathrm{mL}$, which is the concentration of the antioxidant compound that is needed to scavenge half of the DPPH radical in 30 min. The $\mathrm{IC}_{50}$ was determined using the logarithmic regression of the inhibition calculated using the eq 1 below, versus the antioxidant concentration in the $3 \mathrm{~mL}$ reaction mixture. The analyses were performed in triplicate.

$$
\text { Inhibition [\%] }=\frac{\mathrm{Abs}_{\mathrm{DPPH}}-\mathrm{Abs}_{\text {antiox }}}{\mathrm{Abs}_{\mathrm{DPPH}}} \times 100
$$

where $\mathrm{Abs}_{\mathrm{DPPH}}$ is the absorbance after $30 \mathrm{~min}$ of the $\mathrm{DPPH}$ radical solution at $520 \mathrm{~nm}$ in the absence of the antioxidant compound and $\mathrm{Abs}_{\text {antiox }}$ is the absorbance after $30 \mathrm{~min}$ of the DPPH radical solution in the presence of the antioxidant compound.

Oxidation induction time (OIT) was determined by differential scanning calorimetry (DSC). Thermographs were recorded on a Netzsch Polyma 2014 DSC apparatus. DSC data were obtained from about $10 \mathrm{mg}$ of biolubricant sample, which was heated to $180{ }^{\circ} \mathrm{C}$ at a heating rate of $30{ }^{\circ} \mathrm{C} / \mathrm{min}$ and kept isothermally at $180{ }^{\circ} \mathrm{C}$ for $6 \mathrm{~h}$ under a constant air flow of $75 \mathrm{~mL} / \mathrm{min}$. OIT is reported as the onset time of the sample oxidation. The onset time of the oxidation reaction was taken as the intersection of the extrapolated baseline and the tangent line (leading edge) of the exotherm. An example of OIT determination for castor oil is presented in Figure S1A. OIT was determined using the oxidation induction time function in the Proteus Analysis (Netzsch) software. The experiments were perform in triplicate.

The biolubricant viscosity within a shear rate range of $1-1000 \mathrm{~s}^{-1}$ was reported using a TA Instruments Discovery HR 2 rheometer at $25{ }^{\circ} \mathrm{C}$ in a Newtonian regime. A parallel plate geometry was used, using a $40 \mathrm{~mm}$ diameter stainless steel plate on a Peltier temperature control plate.

The evaluation of the tribological properties of the prepared biolubricants was conducted using an SRV4 Test Machine (Optimol Instruments Priiftechnik $\mathrm{GmbH}$ ). The test method, according to ASTM D 6425, has been implemented at the SRV test machine using a test ball (AISI 52100 steel, $60 \mathrm{HRC}$ hardness, $10 \mathrm{~mm}$ diameter) oscillated at a constant frequency $(50 \mathrm{~Hz})$ and stroke amplitude $(1$ $\mathrm{mm}$ ) and under a constant load ( $50 \mathrm{~N}$ for $30 \mathrm{~s}$, then $300 \mathrm{~N}$ for $2 \mathrm{~h}$ ), against a test disk (AISI 521000 steel) that had been moistened with the lubricant $(0.3 \mathrm{~mL})$. The platform to which the disc is attached is held at a constant temperature $\left(80^{\circ} \mathrm{C}\right)$. Balls and disks were washed in petroleum ether in an ultrasonic cleaner for $10 \mathrm{~min}$. Peak values of coefficients of friction are determined and recorded as a function of time (Figure S6). After the test, the wear scar on the ball was measured by means of an optical microscope (Nikon). The planimetric wear of the wear track was determined employing a profilometer (Talysurf CCI optical profiler) in the center of the track length. All experiments were performed in triplicate.

\section{RESULTS AND DISCUSSION}

In this study, four different lignin samples, P1000 (soda pulping lignin from wheat straw), $\mathrm{CLO} \mathrm{MeOH}$ (solvolitically fractionated $\mathrm{P} 1000$ lignin), $\mathrm{Ru} / \mathrm{C}$, and $\mathrm{Pd} / \mathrm{C}$ hexane residues (lignin fractions obtained after Reductive Catalytic Fractionation (RCF), using $\mathrm{Ru} / \mathrm{C}$ or $\mathrm{Pd} / \mathrm{C}$ catalysts on birch wood, respectively) are used as antioxidant additives in biolubricant formulations and compared with a commercial reference, BHT. Here, we compare wheat straw lignins (P1000 and CLO $\mathrm{MeOH}$ ) with birch wood lignins ( $\mathrm{Ru} / \mathrm{C}$ and $\mathrm{Pd} / \mathrm{C}$ hexane residues) processed via either soda pulping (P1000 lignin), solvent fractionation $(\mathrm{CLO} \mathrm{MeOH})$, or RCF $\mathrm{Ru} / \mathrm{C}$ and $\mathrm{Pd} / \mathrm{C}$ hexane residues. The protocols describing how those fractions were obtained are reported in the Experimental Section. Those fractions were selected because upscaling of those processes is currently ongoing and application development is needed for their commercialization. $\mathrm{Ru} / \mathrm{C}$ and $\mathrm{Pd} / \mathrm{C}$ hexane residues contain oligomeric and monomeric fractions $(10 \%$ and $50 \%$ of monomers are present in $\mathrm{Ru} / \mathrm{C}$ and $\mathrm{Pd} / \mathrm{C}$ hexane residue, respectively), while $\mathrm{P} 1000$ lignin and CLO $\mathrm{MeOH}$ consist of oligomeric fractions exclusively (Table S2).

Table 1 summarizes the characteristics of each lignin fraction. In general, all of the samples have a similar amount of phenolic hydroxyl groups, while a larger variation, ranging 
Table 2. Summary of the Esterification Results Based on ${ }^{31} \mathrm{P}$ NMR Spectroscopy

\begin{tabular}{|c|c|c|c|c|c|c|c|c|}
\hline sample & $\begin{array}{c}\text { palmitic ester } \\
\text { moieties } \\
{[\mathrm{mmol} / \mathrm{g}]}\end{array}$ & $\begin{array}{c}\text { esterification } \\
\text { degree }^{b}[\% \text { total } \\
\text { OH }]\end{array}$ & $\begin{array}{l}\text { free phenolic OH } \\
\text { content }[\mathrm{mmol} / \mathrm{g}]\end{array}$ & $\begin{array}{l}\text { free aliphatic OH } \\
\text { content }[\mathrm{mmol} / \mathrm{g}]\end{array}$ & $\begin{array}{l}\text { phenolic OH of }(\mathrm{S} \\
+\mathrm{G}) / \mathrm{H} \text { type ratio }{ }^{a}[\%]\end{array}$ & $\begin{array}{c}M_{\mathrm{w}}^{c} \\
{[\mathrm{kDa}]}\end{array}$ & $\begin{array}{c}M_{\mathrm{n}}^{c} \\
{[\mathrm{kDa}]}\end{array}$ & $\begin{array}{l}\bigoplus^{c} \\
{\left[M_{\mathrm{w}} /\right.} \\
\left.M_{\mathrm{n}}\right]\end{array}$ \\
\hline $\begin{array}{l}\mathrm{Ru} / \mathrm{C} \text { hexane } \\
\text { residue, } \\
\text { palmitoylated }\end{array}$ & 1.91 & 73 & 0.82 & 0.06 & $100 / 0$ & 2.8 & 2.2 & 1.29 \\
\hline $\begin{array}{l}\mathrm{Pd} / \mathrm{C} \text { hexane } \\
\text { residue, } \\
\text { palmitoylated }\end{array}$ & 1.5 & 46 & 2.02 & 0.63 & $99 / 1$ & 1.7 & 2.0 & 1.20 \\
\hline $\begin{array}{l}\mathrm{CLO} \mathrm{MeOH}, \\
\text { palmitoylated }\end{array}$ & 1.61 & 71 & 0.74 & 0.06 & $79 / 21$ & 3.9 & 2.1 & 1.82 \\
\hline $\begin{array}{l}\text { P1000 lignin, } \\
\text { palmitoylated }\end{array}$ & 1.72 & 69 & 0.67 & 0.26 & $90 / 10$ & 9.8 & 5.3 & 1.84 \\
\hline
\end{tabular}

${ }^{a}$ Phenolic $\mathrm{OH}$ of syringyl (S), guaiacyl (G), and p-hydroxyphenyl (H) type ratio determined by ${ }^{31} \mathrm{P}$ NMR spectroscopy, ${ }^{b}$ Calculated as described by Koivu et al. ${ }^{43}$ Calculations are based on a theoretical lignin mass percentage in a lignin ester. $m(\%)$ lignin $=$ $\frac{1-m(\mathrm{H} \%)}{1-m(\mathrm{H} \%)+m(\mathrm{R} \%)} \times 100 \%=\frac{1-\left[\left(\frac{\mathrm{P} a l m \mathrm{Cl}}{\mathrm{Lignin}}\right) \times(\mathrm{OH}) \times M(\mathrm{H})\right]}{1+\left[\left(\frac{\mathrm{PalmCl}}{\mathrm{Lignin}}\right) \times(\mathrm{OH}) \times M(\mathrm{R})\right]} \times 100 \%$, where palmCl/lignin is the molar ratio of added palmitoyl chloride to lignin (equivalents); $(\mathrm{OH})$ is the total hydroxyl content of lignin in $\mathrm{mmol} / \mathrm{g}$; and $m(\mathrm{H} \%)$ and $m(\mathrm{R} \%)$ are mass effects related to the hydrogen $(\mathrm{H})$ and palmitic acyl group (R), where $M(\mathrm{H})=1 \mathrm{~g} / \mathrm{mol}$ and $M(\mathrm{R})=239 \mathrm{~g} / \mathrm{mol}$. ${ }^{c}$ Based on THF GPC, after acetylation, only the oligomeric fraction was quantified therefore it is not fully representative for the whole sample (palmitoylated monomers and dimers with molecular weight below $1000 \mathrm{Da}$ were not quantified)

from 1.27 to $4.33 \mathrm{mmol} \mathrm{OH} / \mathrm{g}$ lignin, is observed for the aliphatic hydroxyl groups. These aliphatic hydroxyl groups are most abundant in $\mathrm{Pd} / \mathrm{C}$ hexane residue, followed by $\mathrm{Ru} / \mathrm{C}$ hexane residue, P1000 lignin, and $\mathrm{CLO} \mathrm{MeOH}$. Carboxylic groups are most abundant in P1000 lignin, followed by CLO $\mathrm{MeOH}, \mathrm{Pd} / \mathrm{C}$, and $\mathrm{Ru} / \mathrm{C}$ hexane residues. A difference in (S $+\mathrm{G}) / \mathrm{H}$ (syringyl (S), guaiacyl (G), and p-hydroxyphenyl $(\mathrm{H})$ ) unit ratios can be observed. $\mathrm{Ru} / \mathrm{C}$ and $\mathrm{Pd} / \mathrm{C}$ hexane residues have a higher amount of syringyl and guaiacyl units, while P1000 lignin and CLO MeOH contain higher amounts of phydroxyphenyl units. This difference is the effect of the used feedstock: birch wood, a hard wood $(\mathrm{Ru} / \mathrm{C}$ and $\mathrm{Pd} / \mathrm{C}$ hexane residues), versus wheat straw (P1000 lignin and CLO MeOH). The weight-average molecular weight $\left(M_{\mathrm{w}}\right)$ and dispersity are the highest for P1000 wheat straw soda lignin, while CLO $\mathrm{MeOH}$, obtained after P1000 lignin methanolysis, demonstrates a lower molecular weight by a factor of 2 compared to $\mathrm{P} 1000$ lignin, along with a narrower dispersity. The $\mathrm{Ru} / \mathrm{C}$ and $\mathrm{Pd} / \mathrm{C}$ hexane residues exhibited very low molecular weights. Monomers, dimers, and oligomers were present in the sample as a result of RCF depolymerization (Figure S2). The observed differences in functional group content and $M_{\mathrm{w}}$ between the four lignin fractions are explained mainly by application of the different process technologies and to a minor extent the biomass source, i.e., lignin isolation from wheat straw via the soda process, followed by methanolysis of the obtained P1000 soda lignin versus the RCF of birch wood.

The above-described lignin fractions could not be dissolved in castor oil, and the resulting dispersions obtained instead were not stable. Therefore, the lignin fractions had to be modified with aliphatic chains to improve the compatibility (miscibility or dispersibility) with castor oil. To increase the lipophilicity of lignin, esterification by palmitic chloride was chosen. ${ }^{14,42,43}$ Importantly, only a partial esterification of the phenolic $\mathrm{OH}$ moieties in the lignin structure was performed, as these $\mathrm{OH}$ groups are responsible for the targeted antioxidant properties. The results of lignin palmitoylation are summarized in Table 2. In all cases, aliphatic hydroxyl groups were modified to a higher extent than phenolic hydroxyl groups. This can be attributed to a depletion of palmitoylating agent and competition between aliphatic and aromatic $\mathrm{OH}$ groups. Pyridine as the catalyst was indeed previously described to favor aliphatic rather than aromatic hydroxyl moieties. ${ }^{44}$ The molecular weight of all the modified fractions increased compared to the unmodified fractions, which is expected (Figure S3). Additionally, GC-FID analysis of palmitoylated lignin fractions (detailed data available in SI, Table S2) revealed that there were no lignin monomers in P1000 or CLO $\mathrm{MeOH}$ palmitoylated fractions and almost no nonpalmitolyated monomeric compounds in $\mathrm{Ru} / \mathrm{C}$ and $\mathrm{Pd} / \mathrm{C}$ samples (below 3.5\%). All of the samples contained some free palmitic acid (4-16 wt \%).

Limited oxidative stability is the main disadvantage of the current industrial use of vegetable oils as lubricants. Therefore, this aspect needs to be improved by either chemical modification of the base oils or by the addition of an antioxidant. Butylated hydroxytoluene (BHT) is a commonly used synthetic antioxidant, next to other antioxidants such as propyl gallate, ascorbyl palmitate, butylated hydroxyanisole, mono-tert-butylhydroquinone, and 4,4'-methylenebis(2,6-ditert-butylphenol), whose role is to increase oxidative stability in lubricants. ${ }^{27,45}$ The mechanism of BHT's antioxidant activity is free radical scavenging by hydrogen atom transfer. ${ }^{46}$ The radical of a phenolic compound such as BHT is more stable than a lipid or a lipid peroxy radical due to the delocalization of the unpaired electron throughout the $\pi$ system in the phenolic ring structure, which is additionally stabilized by the tert-butyl substituent in the para position. Additionally, hydrogen atom transfer between antioxidants like BHT and the lipid peroxy or lipid radicals of oil is thermodynamically driven, hereby blocking the propagation of peroxy radicals within oil structures. Lignin is known for its antioxidant properties: in reactions with free radicals it forms resonance-stabilized radicals via a mechanism similar to BHT. ${ }^{47,48}$ Since lignin has a more complex chemical structure than BHT, additional factors influence lignin's antioxidant activity, such as the molecular weight, the amount of phenolic $\mathrm{OH}$ and methoxy groups (introducing more resonance stabilization), the possible presence of conjugated carbonyl groups in the side chain and aliphatic $\mathrm{OH}$ groups (both having 

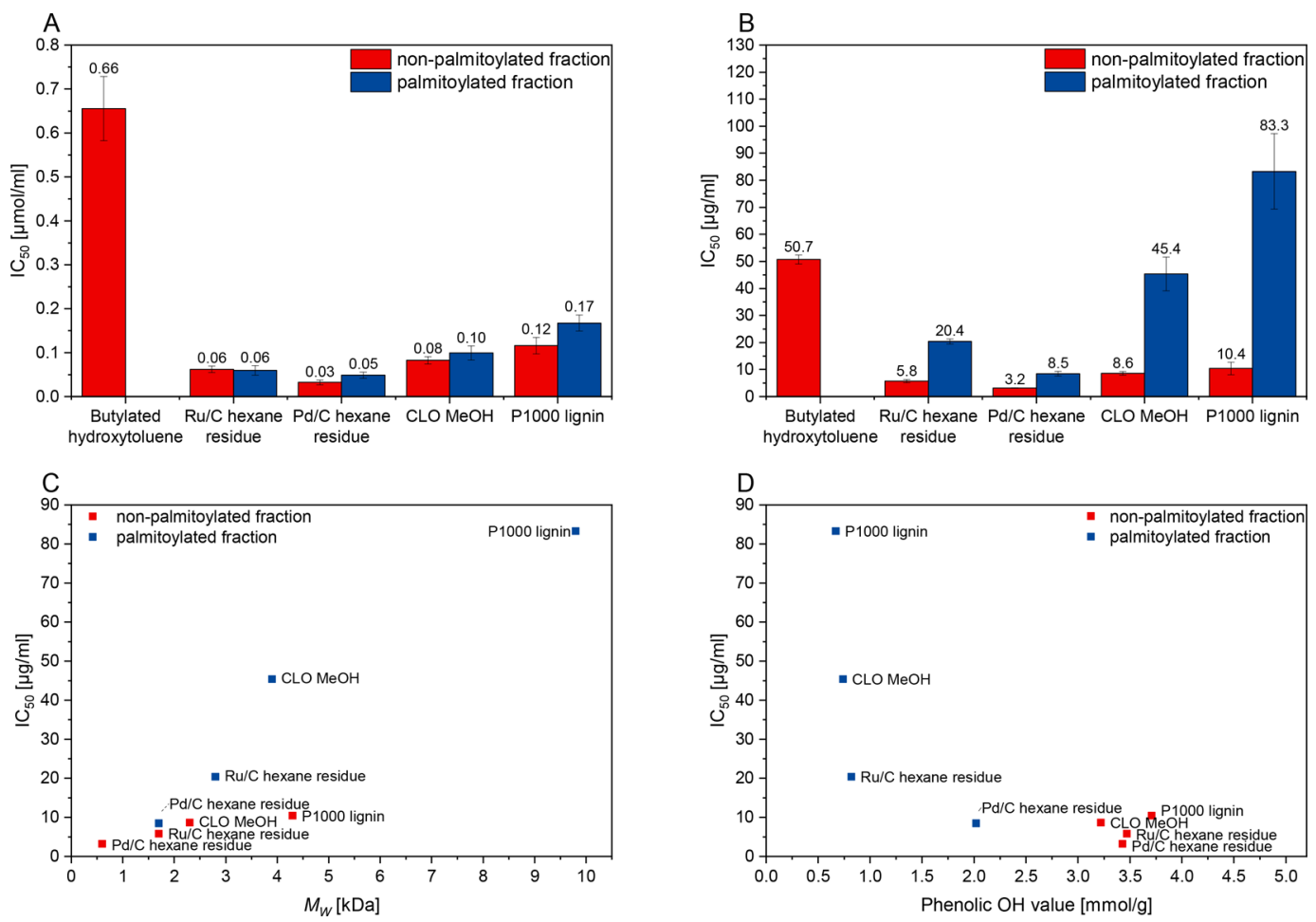

Figure 3. $\mathrm{IC}_{50}$ values of lignin-based modified and unmodified fractions obtained in the DPPH antioxidant activity assays: A, molar-based comparison; $\mathrm{B}$, weight-based comparison; $\mathrm{C}, \mathrm{IC}_{50}$ as a function of $\mathrm{M}_{\mathrm{W}} ; \mathrm{D}, \mathrm{IC}_{50}$ as a function of phenolic $\mathrm{OH}$ value for the different lignin fractions (modified and unmodified).

a negative effect on antioxidant activity)..$^{10,47-55}$ Moreover, carbohydrate impurities can decrease the antioxidant activity due to hydrogen bonding with lignin phenolic groups. ${ }^{48,56}$ The results presented in available literature suggest that the phenolic hydroxyl group content is a very important factor, next to molecular weight, and is responsible for the antioxidant activity of lignin. ${ }^{53,54,56}$ Therefore, all the lignin concentrations in the antioxidant activity assay and the oxidative induction time studies were based only on the phenolic hydroxyl group content.

To compare the antioxidant activity of the lignin fractions under study, the 2,2-diphenyl-1-picrylhydrazyl (DPPH) assay was used to determine radical scavenging activity of the lignin fractions. The activity of each fraction, before and after palmitoylation, was benchmarked with BHT, which is a commonly used antioxidant. The inhibition profile as a function of antioxidant concentration (available in the SI, Figure S4) was used to determine $\mathrm{IC}_{50}$ values. The corresponding data are summarized in Figure 3. $\mathrm{IC}_{50}$ is the concentration of the antioxidant compound required to scavenge $50 \%$ of DPPH radicals. The lower is the $\mathrm{IC}_{50}$ value, the higher is the radical scavenging activity of the component. Pure castor oil and fully palmitoylated P1000 lignin references did not exhibit significant antioxidant activity (available in SI Figure S4).

As palmitoylation will change the chemical properties of the samples, the $\mathrm{IC}_{50}$ values of all samples were presented as both molar and mass concentrations. Generally, antioxidant properties are compared based on $\mathrm{IC}_{50}$ mass concentration, however in this case we aimed to compare the samples before and after palmitoylation based on molar concentration of the phenolic $\mathrm{OH}$ as well. Palmitoylation of lignin caused a significant decrease in the amount of the phenolic $\mathrm{OH}$ groups, which is the moiety responsible for antioxidant activity. Therefore, to fairly compare the antioxidant potential of these samples both manners were used. In Figure $3 \mathrm{~A}$ and $\mathrm{B}$, it is shown that the best results, i.e., the lowest $\mathrm{IC}_{50}$, are obtained for $\mathrm{Pd} / \mathrm{C}$ hexane residue, followed by $\mathrm{Ru} / \mathrm{C}$ hexane residue, $\mathrm{CLO} \mathrm{MeOH}$, and P1000 lignin. The same trend is observed before and after palmitoylation, irrespective of the $\mathrm{IC}_{50}$ calculation on a molar or weight basis. The results on weight basis in Figure $3 \mathrm{~B}-\mathrm{D}$ reveal that, for each lignin sample, modification has a negative influence on the antioxidant activity, as could be expected due to the reduction of free phenolic $\mathrm{OH}$ groups as well as the contribution of the incorporated palmitoyl chain to the increase of $M_{\mathrm{W}}$. BHT is showing similar antioxidant activity compared to palmitoylated $\mathrm{CLO} \mathrm{MeOH}$ and better than palmitoylated P1000 lignin. Notably, the palmitoylated $\mathrm{Ru} / \mathrm{C}$ and $\mathrm{Pd} / \mathrm{C}$ hexane residues outperform $\mathrm{BHT}$ in terms of radical scavenging activity on a weight basis with a factor of 2.5 to 6 , respectively. When the results are standardized based on the molar concentration of free phenolic $\mathrm{OH}$, all lignin-based samples outperform BHT with a factor ranging from 4 (palmitoylated P1000 lignin) to 20 (palmitoylated Pd/C hexane residue sample). Although it was reported in the literature that lignin could have a lower $\mathrm{IC}_{50}$ than $\mathrm{BHT}$, usually the difference was not that pronounced. $29,49,57,58$

The molecular weight of the lignin fractions (Figure $3 \mathrm{C}$ ) partly explains the observed $\mathrm{IC}_{50}$ values: a decreasing molecular weight is favoring better performance of lignin as an antioxidant, a trend that is in line with the literature. ${ }^{49,57,59,60}$ Moreover, methoxy-substituted phenolic units exhibit increased stabilization of the radicals. Therefore, lignin fractions with higher syringyl (two methoxy groups) and guaiacyl (one methoxy group) units are reported to contribute to the increased antioxidant property compared to fractions 
with higher content of p-hydroxyphenyl (one $\mathrm{OH}$ and zero methoxy groups) units. ${ }^{10,47-49,51}$ Thus, the higher content of phenolic $\mathrm{OH}$ of the $\mathrm{S}+\mathrm{G}$ type in nonpalmitoylated $\mathrm{RCF}$ samples $(\mathrm{Ru} / \mathrm{C}$ and $\mathrm{Pd} / \mathrm{C}$ hexane residues) compared to $\mathrm{P} 1000$ samples (CLO MeOH and P1000 lignin) can explain why RCF samples have lower $\mathrm{IC}_{50}$ values than $\mathrm{P} 1000$ derived samples (Table 2). For the $\mathrm{Ru} / \mathrm{C}$ and $\mathrm{Pd} / \mathrm{C}$ hexane residues, the presence of low molecular weight fractions and higher monomer content ( $10 \%$ vs $50 \%$, respectively) may lead to improved antioxidant properties.

Next to the evaluation of antioxidant capabilities of the different lignin fractions, the antioxidant effect of lignin vs BHT in castor oil based lubricants was assessed in oxidative induction time (OIT) studies. This allows for direct evaluation of the resistance to oxidation of formulated lubricants, instead of measuring the scavenging activity of pure antioxidants, as is the case for the DPPH assay. In OIT studies, the radicals are generated in situ, during the exposure of the material to oxygen at elevated temperatures. The antioxidant effect is observed by delay of the starting point of the material oxidation. Oil oxidation is an exothermic process involving release of heat, which is recorded by DSC. Thermal oxidation of triglyceridebased vegetable oils is related to the unsaturation degree of the fatty acid chains. ${ }^{46,61}$ Double bonds are the active sites of oxidation by the free radical mechanism. ${ }^{46,61}$ First, a hydrogen atom from a methylene group next to a double bond in the fatty acid is abstracted, and a lipid radical is formed. This radical subsequently reacts with oxygen, and peroxy radicals are formed. The lipid peroxy radicals can then remove a hydrogen atom from the next fatty acid chain, forming a lipid hydroperoxide and new lipid radical, propagating the autoxidation process. The $\mathrm{O}-\mathrm{O}$ bond in a hydroperoxide functional group can break easily homolytically, explaining that hydroperoxides are a source of more free radicals. Such a branching step leads to the proliferation of radicals and assists in the propagation of more hydroperoxides, which continue to build up in the oil via propagation and branching steps. Ultimately, the hydroperoxides are decomposed into volatile and nonvolatile low molecular weight compounds. Alternatively, polymerization reactions may result in polymeric film formation. ${ }^{46,61}$

To ensure a fair comparison between the lignin samples with varying phenolic $\mathrm{OH}$ content, the amount of palmitoylated lignin dispersed in castor oil was adjusted accordingly. Each lignin sample set was tested with a final concentration of 0.007 , 0.034 , and $0.071 \mathrm{mmol}$ of free phenolic $\mathrm{OH}$ per $1 \mathrm{~g}$ of castor oil. The effect of various lignin-based antioxidants in different concentrations in a castor oil matrix on the thermal oxidation stability was illustrated by OIT studies, visualized in Figure 4 (examples of DSC OIT curves for a concentration of 0.034 mmol antioxidant/g oil are presented in Figure S1). In general, for all tested additives, there is a clear trend of increased OIT with an increased amount of antioxidant within the tested concentration range. The OIT of pure castor oil is $22 \mathrm{~min}$, and the OIT increases slightly after the addition of $0.007 \mathrm{mmol}$ of antioxidant/g of oil. Notably, at higher antioxidant concentrations of $0.034 \mathrm{mmol} / \mathrm{g}$ oil, the OIT improves almost 3 -fold for all of the antioxidants. A further increase to $86-118 \mathrm{~min}$, or a 3.8-5.4 times improvement over pure castor oil, is observed at a concentration of $0.071 \mathrm{mmol} / \mathrm{g}$. As shown in Figure 4, at various concentrations, the tested lignin-based antioxidants have a similar antioxidative influence on castor oil at $180{ }^{\circ} \mathrm{C}$, compared to $\mathrm{BHT}$, except for the highest loading of $\mathrm{Pd} / \mathrm{C}$

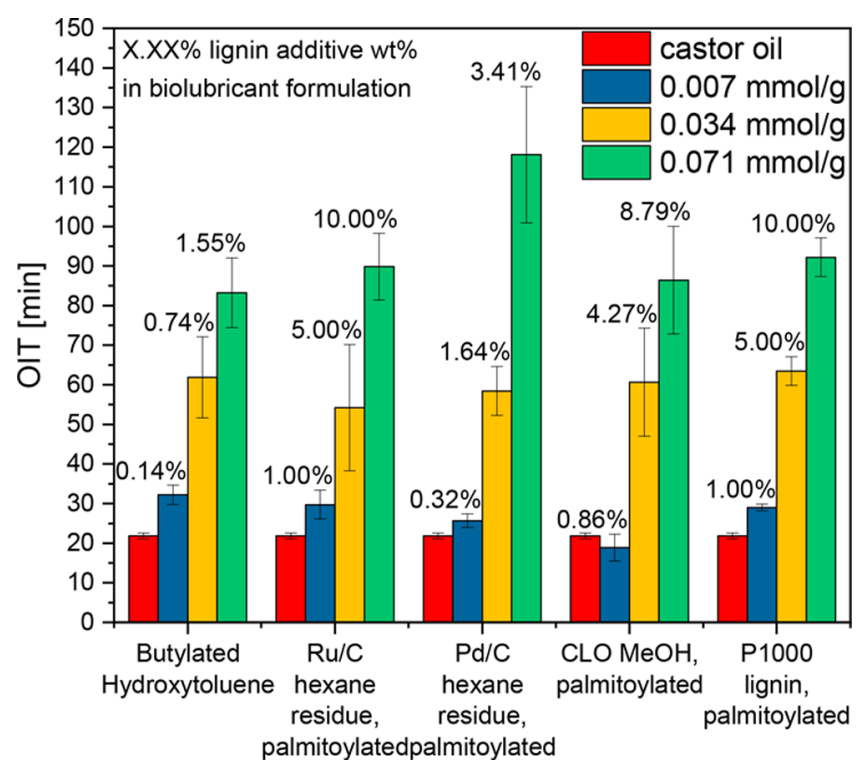

Figure 4. Oxidation induction time of castor oil and biolubricant formulations with varying concentrations of esterified lignin-based additives, determined by DSC at $180{ }^{\circ} \mathrm{C}$ under an air flow.

palmitoylated hexane residue, which provides superior thermal oxidative stability to the oil, by almost 1.5 times compared to BHT. OIT of fully palmitoylated P1000 lignin was 25 and 27 min for 5 and $10 \mathrm{wt} \%$, respectively. This difference is insignificant compared with other lignin fractions described in this study, and we therefore prove that lignin antioxidant performance is strongly related to its phenolic $\mathrm{OH}$ content. Other works, such as the findings of Kasprzycka-Guttman and Odzeniak, showed that the addition of lignin to arachide oil improves OIT slightly more than BHT. ${ }^{28}$ Chandrasekaran et al. showed that the addition of lignin pyrolisate bio-oil exhibited similar antioxidant performance to BHT in soy methyl ester biodiesel. ${ }^{24}$

Viscosity is an important rheological lubricant parameter, since it determines the lubricant's resistance to flow. The rheological behavior of a given lubricant is determined by the base oil and the additives. For instance, most of the oils are exhibiting Newtonian behavior, while lubricating greases and multigrade oils containing viscosity modifiers are often characteried by non-Newtonian behavior, such as shear thinning. ${ }^{62}$ As depicted in Figure 5A, the difference between viscosities at high and low shear rates is marginal for BHT, modified $\mathrm{Ru} / \mathrm{C}$, and $\mathrm{Pd} / \mathrm{C}$ hexane residues in castor oil based dispersions, indicating Newtonian behavior. The dispersions containing $\mathrm{CLO} \mathrm{MeOH}$ and $\mathrm{P} 1000$ modified fractions, show shear thinning behavior, which becomes more pronounced at higher additive concentrations (see the example in Figure 5B). Shear thinning is generally considered to be a result of microscale structural rearrangements and changes in molecular conformations within the fluid that facilitate shearing. ${ }^{63}$ Shear thinning is often observed in lubricants and can affect the behavior of the lubricant at different deformation rates. NonNewtonian samples were fitted in the Sisko model (Table S3) to determine their infinite shear viscosity, which is comparable with their viscosity at $1000 \mathrm{~s}^{-1}$. Moreover, the addition of lignin-based additives affects the viscosity of the biolubricant formulation (Figure 5B). Relative to castor oil, the increase of the relative viscosity is the most pronounced for $\mathrm{P} 1000$ and $\mathrm{CLO} \mathrm{MeOH}$ palmitoylated lignins (Figure 5C) rather than 

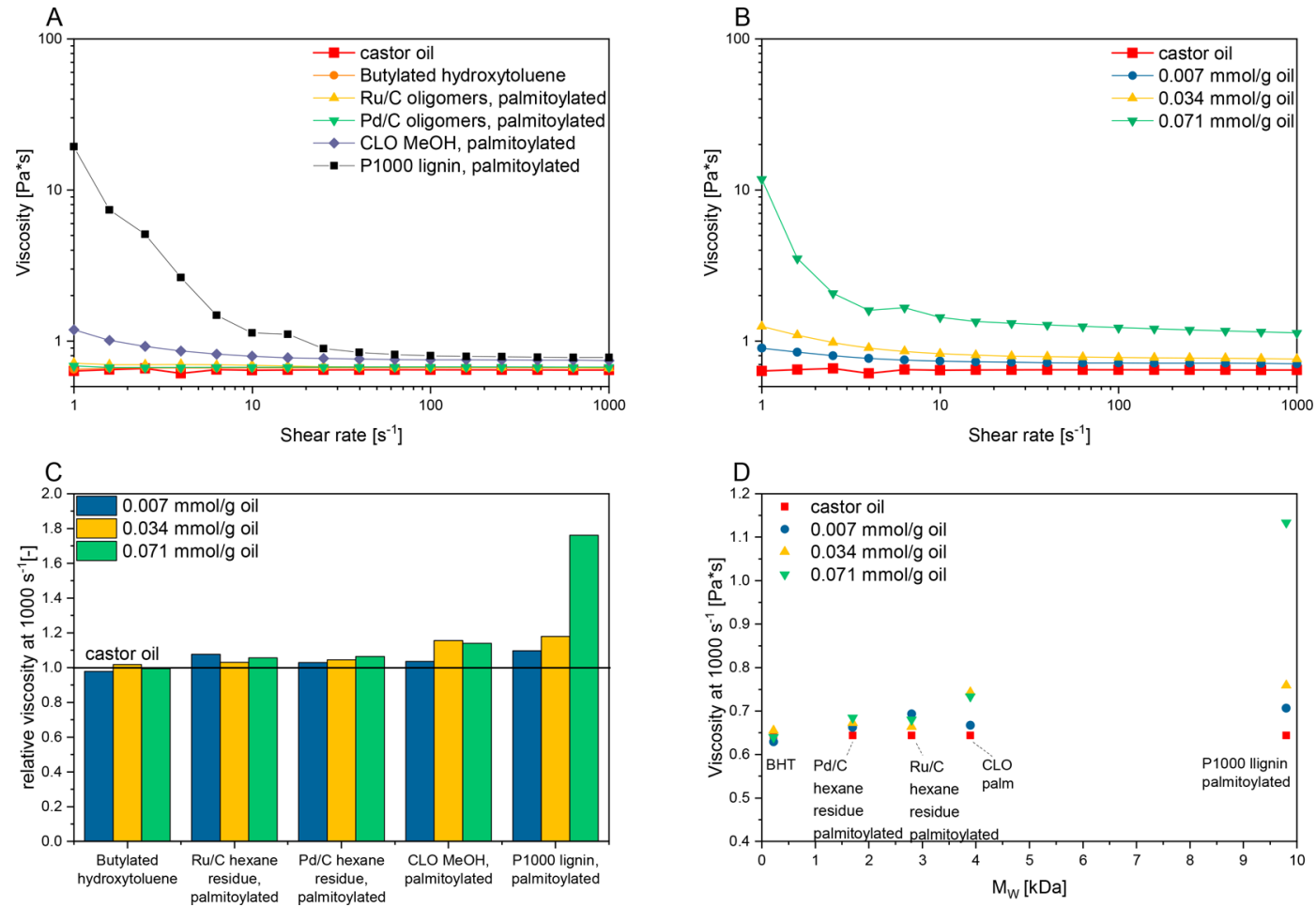

Figure 5. (A) Viscosity as a function of shear rate of castor oil and biolubricant formulations with esterified lignin-based additives (0.034 mmol/g oil additive), (B) comparison of the viscosity difference as a function of lignin concentration (example: P1000 lignin palmitoylated), (C) relative viscosity of the biolubricant formulations compared to pure castor oil, (D) viscosity at high shear rate of castor oil and biolubricant formulations as a function of molecular weight of esterified lignin-based additives.

$\mathrm{Ru} / \mathrm{C}$ and $\mathrm{Pd} / \mathrm{C}$ palmitoylated hexane residues. BHT, $\mathrm{Ru} / \mathrm{C}$, and $\mathrm{Pd} / \mathrm{C}$ lignin oligomers have a small effect on the viscosity of the formulations; the increase is below $6 \%$ for the highest concentrations, while for P1000 lignin we observe up to an $80 \%$ increase. This phenomenon correlates well with the increased molecular weights of $\mathrm{P} 1000$ and $\mathrm{CLO} \mathrm{MeOH}$ lignins compared to $\mathrm{BHT}, \mathrm{Ru} / \mathrm{C}$, and $\mathrm{Pd} / \mathrm{C}$ palmitoylated hexane residues (Figure 5D).

Vegetable oils are known for their excellent tribological performance, and the aim of this work was to maintain them in the lubricants formulations with lignin-based antioxidative additives. The main goal of using lubricants in the first place is protection of the metal surface and heat transfer from friction spots. In the case of vegetable oils, consisting of triglycerides, surface protection is attained through adsorption of the polar part of the oil molecules (ester groups in triglycerides) to the metal surface, resulting in the creation of a barrier, which is responsible for decreasing the coefficient of friction., ${ }^{4,64}$ Previously, lignin was demonstrated to possess antiwear properties in matrices such as various ionic liquids, ${ }^{65,66} \mathrm{PEG}$, and ethylene glycol. ${ }^{22,67,68}$

As shown in Figure 6A, lignin-based additives and BHT demonstrate minor to no effect in decreasing the coefficient of friction between the metal surfaces, compared to castor oil. A similar coefficient of friction, ranging between 0.10 and 0.13 , was obtained for all formulations, in line with other vegetable oils. $^{69,70}$ A desired reduction of the wear volume (Figure 6BD) was also observed in several of the tested biolubricant formulations. It is ranging from 0.004 to $0.006 \mathrm{~mm}^{3}$ for the formulations containing lignin-based additives, while for pure castor oil the value is $0.006 \mathrm{~mm}^{3}$. BHT and the palmitoylated $\mathrm{Pd} / \mathrm{C}$ hexane residue demonstrate the biggest reduction in wear volume, which is $30-40 \%$ decreased compared to the wear volume caused by castor oil. The remaining lignin samples caused a reduction of the wear volume, while at some concentrations no significant difference was observed compared to castor oil. However, the wear scar diameter is slightly higher when the additive is wear volume by less than $25 \%$, added, in the range of 1.04-1.19 mm, while pure castor oil caused a $1.07 \mathrm{~mm}$ scar (Figure S5). Most of the formulations with lignin additives exhibited a similar wear scar diameter as the BHT containing formulations. Although the scar diameter is similar or slightly higher, its depth is lower than for the castor oil reference (Figure 6C,D, Table S4), which results in a reduction of the wear volume. Overall, when considering the three tested tribological parameters, $\mathrm{Pd} / \mathrm{C}$ palmitoylated hexane residue demonstrated the best results, and it is comparable with BHT performance. Those results indicate that lignin-based antioxidants have the potential to create a good quality lubricating film, and some of them bring antiwear properties to the above-mentioned biolubricant formulations.

\section{CONCLUSIONS}

Poor thermo-oxidative stability is the main disadvantage of the use of pure vegetable oil as a biolubricant. In this work, we successfully demonstrate the use of novel, lignin-based antioxidant additives in vegetable oil formulations. Four different lignin fractions were partially modified by the introduction of palmitoyl moieties, in order to increase their lipophilicity, after which good dispersibility in the castor oil matrix was demonstrated. All studied lignin-based antioxidants were benchmarked with BHT, a commercially used antioxidant. DPPH assays on modified and unmodified lignin fractions proved increased radical scavenging properties of 

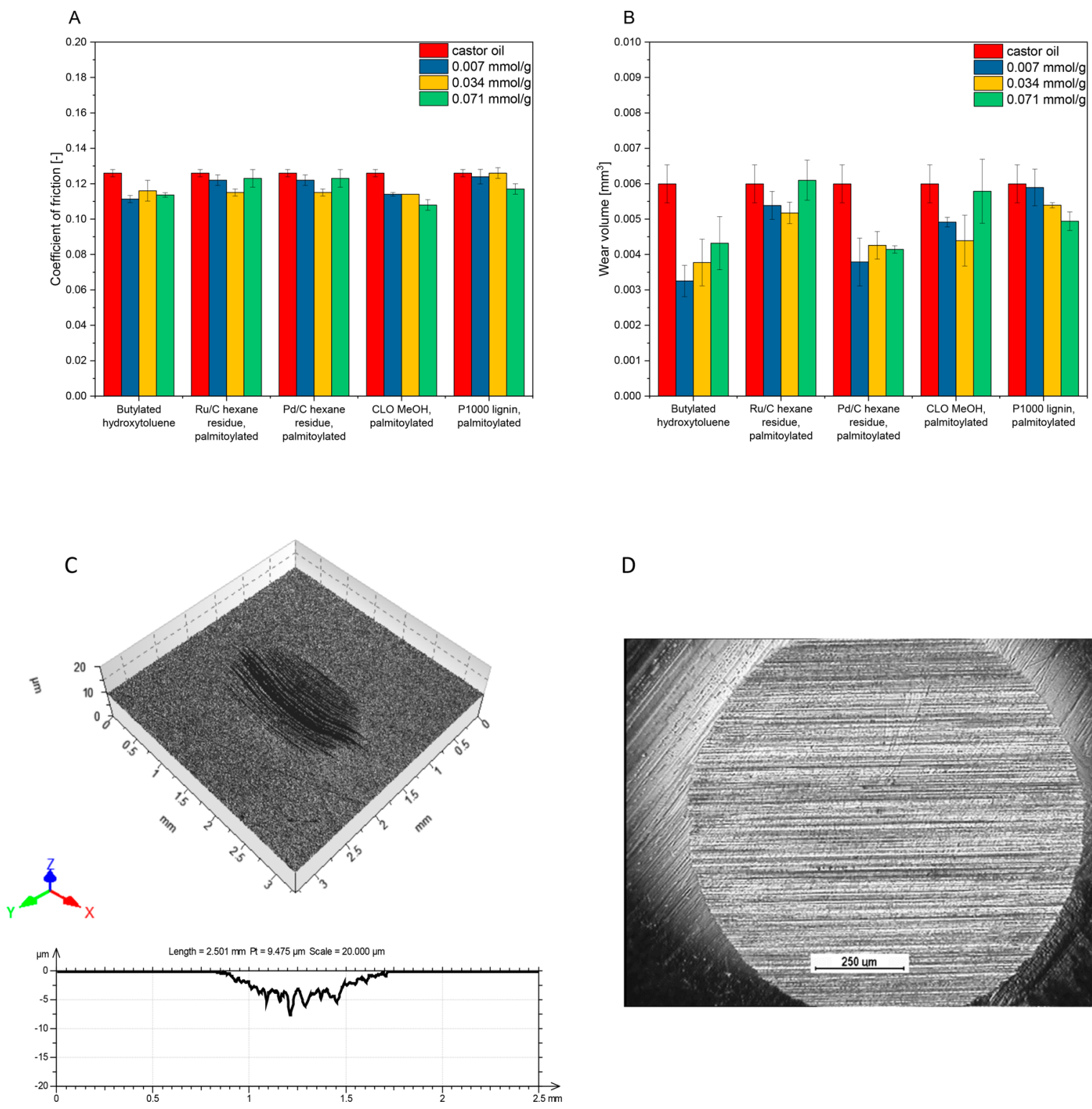

D

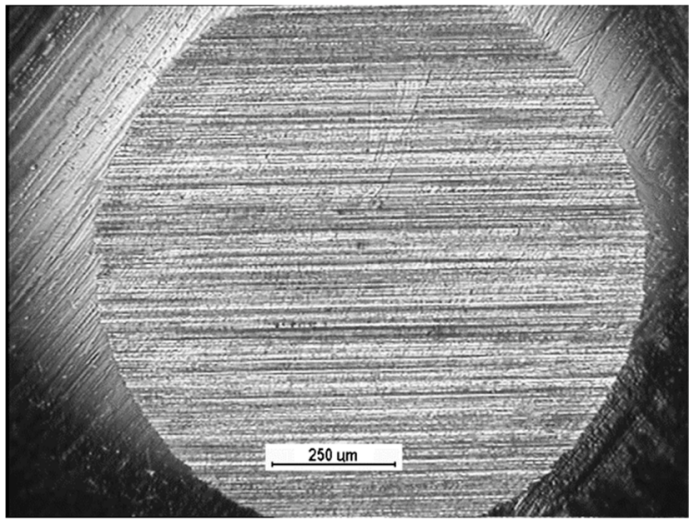

Figure 6. Tribology results of castor oil and biolubricant formulations with esterified lignin-based additives: (A) coefficient of friction, (B) wear volume, (C) 3D image and profile of the wear track in the disc, (D) scars in the ball (C, D example: Pd/C hexane residue, palmitoylated, 0.034 $\mathrm{mmol} / \mathrm{g}$ oil biolubricant).

these lignins compared to BHT. The best results were obtained with low molecular weight lignin-based fractions possessing a high $\mathrm{S}+\mathrm{G}$ hydroxyl content. From the biolubricant perspective, an especially interesting additive was palmitoylated $\mathrm{Pd} / \mathrm{C}$ hexane residue obtained by reductive catalytic fractionation (RCF) of birch wood, which showed better OIT than BHT, while the rest of the additives showed similar performance with BHT. Moreover, formulations with modified lignin-based additives exhibited lubrication properties comparable to BHT in tribological and rheological tests. This proof-of-principle application research is providing an added value for both biomaterials, lignin and castor oil, by showing more possibilities in their valorization. We believe that it is possible to use these materials for other applications than biolubricants, such as cosmetics and pharmaceutics, due to lignin's biocompatibility and low cytotoxicity.

\section{ASSOCIATED CONTENT}

\section{Supporting Information}

The Supporting Information is available free of charge at https://pubs.acs.org/doi/10.1021/acssuschemeng.1c02799.

Comparison of weight percentage of modified lignin in biolubricants formulations; examples of DSC oxidation induction time curves of castor oil and biolubricant formulations with $0.034 \mathrm{mmol} / \mathrm{g}$ oil esterified ligninbased additives; monomer composition of the oligomeric lignin based fractions before and after esterification determined by GC-FID analysis; overlay of the GPC traces of the unmodified lignin fractions; overlay of the GPC traces of the modified lignin fractions; inhibition curves of castor oil, BHT, modified and nonmodified lignin fractions obtained in the DPPH antioxidant activity assay; parameters of the Sisko model for non-Newtonian biolubricant formulations; tribology results of castor oil and biolubricant formulations with 
esterified lignin-based additives, wear scar diameter; coefficients of friction as a function of time; 3D images and profiles of the wear track in the disc and scars in the balls (PDF)

\section{AUTHOR INFORMATION}

\section{Corresponding Author}

Katrien V. Bernaerts - Maastricht University, Faculty of Science and Engineering, Brightlands Chemelot Campus, Aachen-Maastricht Institute for Biobased Materials (AMIBM), 6167 RD Geleen, The Netherlands; 10 orcid.org/ 0000-0002-2939-2963; Email: katrien.bernaerts@ maastrichtuniversity.nl

\section{Authors}

Monika A. Jedrzejczyk - Maastricht University, Faculty of Science and Engineering, Brightlands Chemelot Campus, Aachen-Maastricht Institute for Biobased Materials (AMIBM), 6167 RD Geleen, The Netherlands

Sander Van den Bosch - Center for Sustainable Catalysis and Engineering, KU Leuven, 3001 Heverlee, Belgium; (1) orcid.org/0000-0001-6180-721X

Joost Van Aelst - Center for Sustainable Catalysis and Engineering, KU Leuven, 3001 Heverlee, Belgium

Korneel Van Aelst - Center for Sustainable Catalysis and Engineering, KU Leuven, 3001 Heverlee, Belgium

Panos D. Kouris - Department of Chemical Engineering and Chemistry, Eindhoven University of Technology, $5600 \mathrm{MB}$ Eindhoven, The Netherlands

Mohamed Moalin - Research Centre Material Sciences, Zuyd University of Applied Science, 6400 AN Heerlen, The Netherlands; Department of Pharmacology and Toxicology, Maastricht University, 6200 MD Maastricht, The Netherlands

Guido R. M. M. Haenen - Department of Pharmacology and Toxicology, Maastricht University, 6200 MD Maastricht, The Netherlands

Michael D. Boot - Department of Chemical Engineering and Chemistry, Eindhoven University of Technology, $5600 \mathrm{MB}$ Eindhoven, The Netherlands

Emiel J. M. Hensen - Department of Chemical Engineering and Chemistry, Eindhoven University of Technology, 5600 MB Eindhoven, The Netherlands; (1) orcid.org/0000-00029754-2417

Bert Lagrain - Center for Sustainable Catalysis and Engineering, KU Leuven, 3001 Heverlee, Belgium; ○ orcid.org/0000-0002-9707-1977

Bert F. Sels - Center for Sustainable Catalysis and Engineering, KU Leuven, 3001 Heverlee, Belgium;

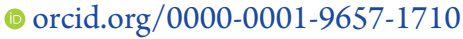

Complete contact information is available at:

https://pubs.acs.org/10.1021/acssuschemeng.1c02799

\section{Author Contributions}

The manuscript was written through contributions of all authors. All authors have given approval to the final version of the manuscript.

\section{Funding}

This work was funded by Chemelot InSciTe (project Lignin Riches), by the European Interreg V Flanders-The Netherlands program BIO-HArT and by the Ministry of Economic Affairs and Climate from The Netherlands. Financial support for K.V.A. (Catalisti Moonshot program Flemish government, project NIBCON), J.V.A. (Industrial Research Fund KU Leuven, IOF mandate), and S.V.d.B. (Flanders Innovation \& Entrepreneurship (VLAIO), innovation mandate) are acknowledged. B.S. acknowledges additional financial support from the project BioFact through the Excellence of Science (EoS) program, and the project $\mathrm{AD}-\mathrm{LIBIO}$ through the Belgian energy transition fund (ETF).

Notes

The authors declare no competing financial interest.

\section{ACKNOWLEDGMENTS}

The authors would like to acknowledge Gijs de Kort from Aachen-Maastricht Institute for Biobased Materials (AMIBM) at Maastricht University for the help with interpretation of the rheology experiments.

\section{ABBREVIATIONS}

BHT, butylated hydroxytoluene; DSC, differential scanning calorimetry; DPPH, 2,2-diphenyl-1-picrylhydrazyl; GC-FID, gas chromatography with flame ionization detector; GPC, gel permeation chromatography; $M_{\mathrm{n}}$, number-average molecular weight; $M_{w}$, weight-average molecular weight; NMR, nuclear magnetic resonance; OIT, oxidation induction time; PEG, polyethylene glycol; RCF, reductive catalytic fractionation; S/ $\mathrm{G} / \mathrm{H}$ units ratio, syringyl (S), guaiacyl (G), and phydroxyphenyl $(\mathrm{H})$ units ratio; $Ð$, dispersity

\section{REFERENCES}

(1) Syahir, A. Z.; Zulkifli, N. W. M.; Masjuki, H. H.; Kalam, M. A.; Alabdulkarem, A.; Gulzar, M.; Khuong, L. S.; Harith, M. H. A review on bio-based lubricants and their applications. J. Cleaner Prod. 2017, 168, 997-1016.

(2) Murru, C.; Badía-Laíño, R.; Díaz-García, M. E. Oxidative Stability of Vegetal Oil-Based Lubricants. ACS Sustainable Chem. Eng. 2021, 9 (4), 1459-1476.

(3) Zainal, N. A.; Zulkifli, N. W. M.; Gulzar, M.; Masjuki, H. H. A review on the chemistry, production, and technological potential of bio-based lubricants. Renewable Sustainable Energy Rev. 2018, 82, 80102.

(4) Panchal, T. M.; Patel, A.; Chauhan, D. D.; Thomas, M.; Patel, J. V. A methodological review on bio-lubricants from vegetable oil based resources. Renewable Sustainable Energy Rev. 2017, 70, 65-70.

(5) Quinchia, L. A.; Delgado, M. A.; Reddyhoff, T.; Gallegos, C.; Spikes, H. A. Tribological studies of potential vegetable oil-based lubricants containing environmentally friendly viscosity modifiers. Tribol. Int. 2014, 69, 110-117.

(6) Prasad, R. B. N.; Rao, B. V. S. K. Chemical Derivatization of Castor Oil and Their Industrial Utilization. Fatty Acids 2017, 279303.

(7) Sels, B.; Philippaerts, A. Conjugated Linoleic Acids and Conjugated Vegetable Oils; Royal Society of Chemistry, 2014; pp 117-130.

(8) Patel, V. R.; Dumancas, G. G.; Viswanath, L. C. K.; Maples, R.; Subong, B. J. J. Castor Oil: Properties, Uses, and Optimization of Processing Parameters in Commercial Production. Lipid Insights 2016, 9, LPI.S40233.

(9) Kai, D.; Tan, M. J.; Chee, P. L.; Chua, Y. K.; Yap, Y. L.; Loh, X. J. Towards lignin-based functional materials in a sustainable world. Green Chem. 2016, 18 (5), 1175-1200.

(10) Kim, J.-Y.; Johnston, P. A.; Lee, J. H.; Smith, R. G.; Brown, R. C. Improving Lignin Homogeneity and Functionality via Ethanolysis for Production of Antioxidants. ACS Sustainable Chem. Eng. 2019, 7 (3), 3520-3526.

(11) Liu, X.; Bouxin, F. P.; Fan, J.; Budarin, V. L.; Hu, C.; Clark, J. $\mathrm{H}$. Recent Advances in the Catalytic Depolymerization of Lignin 
towards Phenolic Chemicals: A Review. ChemSusChem 2020, 13 (17), 4296-4317.

(12) Chio, C.; Sain, M.; Qin, W. Lignin utilization: A review of lignin depolymerization from various aspects. Renewable Sustainable Energy Rev. 2019, 107, 232-249.

(13) Sun, Z.; Fridrich, B.; de Santi, A.; Elangovan, S.; Barta, K. Bright Side of Lignin Depolymerization: Toward New Platform Chemicals. Chem. Rev. 2018, 118 (2), 614-678.

(14) Wang, C.; Kelley, S. S.; Venditti, R. A. Lignin-Based Thermoplastic Materials. ChemSusChem 2016, 9 (8), 770-783.

(15) Schutyser, W.; Renders, T.; Van den Bosch, S.; Koelewijn, S. F.; Beckham, G. T.; Sels, B. F. Chemicals from lignin: an interplay of lignocellulose fractionation, depolymerisation, and upgrading. Chem. Soc. Rev. 2018, 47 (3), 852-908.

(16) Acar, N.; Kuhn, E.; Franco, J. Tribological and Rheological Characterization of New Completely Biogenic Lubricating Greases: A Comparative Experimental Investigation. Lubricants 2018, 6 (2), 4556.

(17) Gallego, R.; Arteaga, J. F.; Valencia, C.; Díaz, M. J.; Franco, J. M. Gel-Like Dispersions of HMDI-Cross-Linked Lignocellulosic Materials in Castor Oil: Toward Completely Renewable Lubricating Grease Formulations. ACS Sustainable Chem. Eng. 2015, 3 (9), 21302141.

(18) Borrero-López, A. M.; Martín-Sampedro, R.; Ibarra, D.; Valencia, C.; Eugenio, M. E.; Franco, J. M. Evaluation of ligninenriched side-streams from different biomass conversion processes as thickeners in bio-lubricant formulations. Int. J. Biol. Macromol. 2020, 162, 1398-1413.

(19) Delgado, M. A.; Cortés-Triviño, E.; Valencia, C.; Franco, J. M. Tribological study of epoxide-functionalized alkali lignin-based gellike biogreases. Tribol. Int. 2020, 146, 106231.

(20) Hua, J.; Shi, Y. Non-corrosive Green Lubricant With Dissolved Lignin in Ionic Liquids Behave as Ideal Lubricants for Steel-DLC Applications. Front. Chem. 2019, 7 (857), 1-8.

(21) Mu, L.; Shi, Y.; Guo, X.; Wu, J.; Ji, T.; Chen, L.; Feng, X.; Lu, X.; Hua, J.; Zhu, J. Enriching Heteroelements in Lignin as Lubricating Additives for Bioionic Liquids. ACS Sustainable Chem. Eng. 2016, 4 (7), 3877-3887.

(22) Mu, L.; Shi, Y.; Wang, H.; Zhu, J. Lignin in Ethylene Glycol and Poly(ethylene glycol): Fortified Lubricants with Internal Hydrogen Bonding. ACS Sustain. ACS Sustainable Chem. Eng. 2016, 4 (3), $1840-1849$.

(23) Cortés-Triviño, E.; Valencia, C.; Franco, J. M. Influence of epoxidation conditions on the rheological properties of gel-like dispersions of epoxidized kraft lignin in castor oil. Holzforschung 2017, 71 (10), 777-784.

(24) Chandrasekaran, S. R.; Murali, D.; Marley, K. A.; Larson, R. A.; Doll, K. M.; Moser, B. R.; Scott, J.; Sharma, B. K. Antioxidants from Slow Pyrolysis Bio-Oil of Birch Wood: Application for Biodiesel and Biobased Lubricants. ACS Sustainable Chem. Eng. 2016, 4 (3), 14141421.

(25) Larson, R. A.; Sharma, B. K.; Marley, K. A.; Kunwar, B.; Murali, D.; Scott, J. Potential antioxidants for biodiesel from a softwood lignin pyrolyzate. Ind. Crops Prod. 2017, 109, 476-482.

(26) Cesari, L.; Mutelet, F.; Canabady-Rochelle, L. Antioxidant properties of phenolic surrogates of lignin depolymerisation. Ind. Crops Prod. 2019, 129, 480-487.

(27) Quinchia, L. A.; Delgado, M. A.; Valencia, C.; Franco, J. M.; Gallegos, C. Natural and Synthetic Antioxidant Additives for Improving the Performance of New Biolubricant Formulations. J. Agric. Food Chem. 2011, 59 (24), 12917-12924.

(28) Kasprzycka-Guttman, T.; Odzeniak, D. Antioxidant properties of lignin and its fractions. Thermochim. Acta 1994, 231, 161-168.

(29) Kaur, R.; Uppal, S. K. Structural characterization and antioxidant activity of lignin from sugarcane bagasse. Colloid Polym. Sci. 2015, 293 (9), 2585-2592.

(30) Kouris, P. D.; van Osch, D. J. G. P.; Cremers, G. J. W.; Boot, M. D.; Hensen, E. J. M. Mild thermolytic solvolysis of technical lignins in polar organic solvents to a crude lignin oil. Sustainable Energy Fuels 2020, 4 (12), 6212-6226.

(31) Liao, Y.; Koelewijn, S.-F.; Van den Bossche, G.; Van Aelst, J.; Van den Bosch, S.; Renders, T.; Navare, K.; Nicolaï, T.; Van Aelst, K.; Maesen, M.; Matsushima, H.; Thevelein, J. M.; Van Acker, K.; Lagrain, B.; Verboekend, D.; Sels, B. F. A sustainable wood biorefinery for low-carbon footprint chemicals production. Science 2020, 367 (6484), 1385-1390.

(32) Abu-Omar, M. M.; Barta, K.; Beckham, G. T.; Luterbacher, J. S.; Ralph, J.; Rinaldi, R.; Román-Leshkov, Y.; Samec, J. S. M.; Sels, B. F.; Wang, F. Guidelines for performing lignin-first biorefining. Energy Environ. Sci. 2021, 14 (1), 262-292.

(33) Van Aelst, K.; Van Sinay, E.; Vangeel, T.; Cooreman, E.; Van den Bossche, G.; Renders, T.; Van Aelst, J.; Van den Bosch, S.; Sels, B. F. Reductive catalytic fractionation of pine wood: elucidating and quantifying the molecular structures in the lignin oil. Chem. Sci. 2020, 11 (42), 11498-11508.

(34) Cooreman, E.; Vangeel, T.; Van Aelst, K.; Van Aelst, J.; Lauwaert, J.; Thybaut, J. W.; Van den Bosch, S.; Sels, B. F. Perspective on Overcoming Scale-Up Hurdles for the Reductive Catalytic Fractionation of Lignocellulose Biomass. Ind. Eng. Chem. Res. 2020, 59 (39), 17035-17045.

(35) van Baarle, D. Vertoro scales up oil production from lignin. https://www.industryandenergy.eu/biobased-economy/vertoroscales-up-oil-production-from-lignin (accessed January 7, 2021).

(36) Kouris, P. D.; Boot, M. D.; Hensen, E. J. M.; Oevering, H. A method for obtaining a stable lignin: polar organic solvent composition via mild solvolytic modifications. WO2019/053287, 2019.

(37) Van den Bosch, S.; Schutyser, W.; Vanholme, R.; Driessen, T.; Koelewijn, S. F.; Renders, T.; De Meester, B.; Huijgen, W. J. J.; Dehaen, W.; Courtin, C. M.; Lagrain, B.; Boerjan, W.; Sels, B. F. Reductive lignocellulose fractionation into soluble lignin-derived phenolic monomers and dimers and processable carbohydrate pulps. Energy Environ. Sci. 2015, 8 (6), 1748-1763.

(38) Korntner, P.; Sumerskii, I.; Bacher, M.; Rosenau, T.; Potthast, A. Characterization of technical lignins by NMR spectroscopy: optimization of functional group analysis by 31P NMR spectroscopy. Holzforschung 2015, 69 (6), 807-814.

(39) Meng, X.; Crestini, C.; Ben, H.; Hao, N.; Pu, Y.; Ragauskas, A. J.; Argyropoulos, D. S. Determination of hydroxyl groups in biorefinery resources via quantitative 31P NMR spectroscopy. Nat. Protoc. 2019, 14 (9), 2627-2647.

(40) Gosselink, R. J. A.; Abächerli, A.; Semke, H.; Malherbe, R.; Käuper, P.; Nadif, A.; van Dam, J. E. G. Analytical protocols for characterisation of sulphur-free lignin. Ind. Crops Prod. 2004, 19 (3), 271-281.

(41) de Menezes Nogueira, I.; Avelino, F.; de Oliveira, D. R.; Souza, N. F.; Rosa, M. F.; Mazzetto, S. E.; Lomonaco, D. Organic solvent fractionation of acetosolv palm oil lignin: The role of its structure on the antioxidant activity. Int. J. Biol. Macromol. 2019, 122, 1163-1172.

(42) Pawar, S. N.; Venditti, R. A.; Jameel, H.; Chang, H.-M.; Ayoub, A. Engineering physical and chemical properties of softwood kraft lignin by fatty acid substitution. Ind. Crops Prod. 2016, 89, 128-134.

(43) Koivu, K. A. Y.; Sadeghifar, H.; Nousiainen, P. A.; Argyropoulos, D. S.; Sipilä, J. Effect of Fatty Acid Esterification on the Thermal Properties of Softwood Kraft Lignin. ACS Sustainable Chem. Eng. 2016, 4 (10), 5238-5247.

(44) Guo, Z.-X.; Gandini, A.; Pla, F. Polyesters from lignin. 1. The reaction of kraft lignin with dicarboxylic acid chlorides. Polym. Int. 1992, 27 (1), 17-22.

(45) Yehye, W. A.; Rahman, N. A.; Ariffin, A.; Abd Hamid, S. B.; Alhadi, A. A.; Kadir, F. A.; Yaeghoobi, M. Understanding the chemistry behind the antioxidant activities of butylated hydroxytoluene (BHT): A review. Eur. J. Med. Chem. 2015, 101, 295-312.

(46) Choe, E.; Min, D. B. Mechanisms of Antioxidants in the Oxidation of Foods. Compr. Rev. Food Sci. Food Saf. 2009, 8 (4), 345358. 
(47) Ponomarenko, J.; Dizhbite, T.; Lauberts, M.; Viksna, A.; Dobele, G.; Bikovens, O.; Telysheva, G. Characterization of Softwood and Hardwood LignoBoost Kraft Lignins with Emphasis on their Antioxidant Activity. BioResources 2014, 9 (2), 2051-2068.

(48) Espinoza-Acosta, J. L.; Torres-Chávez, P. I.; Ramírez-Wong, B.; López-Saiz, C. M.; Montaño-Leyva, B. Antioxidant, Antimicrobial, and Antimutagenic Properties of Technical Lignins and Their Applications. BioResources 2016, 11 (2), 5452-5481.

(49) Majira, A.; Godon, B.; Foulon, L.; van der Putten, J. C.; Cezard, L.; Thierry, M.; Pion, F.; Bado-Nilles, A.; Pandard, P.; Jayabalan, T.; Aguie-Beghin, V.; Ducrot, P. H.; Lapierre, C.; Marlair, G.; Gosselink, R. J. A.; Baumberger, S.; Cottyn, B. Enhancing the Antioxidant Activity of Technical Lignins by Combining Solvent Fractionation and Ionic-Liquid Treatment. ChemSusChem 2019, 12 (21), 47994809.

(50) Pan, X.; Kadla, J. F.; Ehara, K.; Gilkes, N.; Saddler, J. N. Organosolv Ethanol Lignin from Hybrid Poplar as a Radical Scavenger: Relationship between Lignin Structure, Extraction Conditions, and Antioxidant Activity. J. Agric. Food Chem. 2006, 54 (16), 5806-5813.

(51) Alzagameem, A.; Khaldi-Hansen, B. E.; Buchner, D.; Larkins, M.; Kamm, B.; Witzleben, S.; Schulze, M. Lignocellulosic Biomass as Source for Lignin-Based Environmentally Benign Antioxidants. Molecules 2018, 23 (10), 2664-2689.

(52) Dizhbite, T.; Telysheva, G.; Jurkjane, V.; Viesturs, U. Characterization of the radical scavenging activity of lignins-natural antioxidants. Bioresour. Technol. 2004, 95 (3), 309-317.

(53) Sadeghifar, H.; Argyropoulos, D. S. Correlations of the Antioxidant Properties of Softwood Kraft Lignin Fractions with the Thermal Stability of Its Blends with Polyethylene. ACS Sustainable Chem. Eng. 2015, 3 (2), 349-356.

(54) Qin, Z.; Liu, H.-M.; Gu, L.-B.; Sun, R.-C.; Wang, X.-D. Lignin as a Natural Antioxidant: Property-Structure Relationship and Potential Applications. In Reactive and Functional Polymers Vol. One: Biopolymers, Polyesters, Polyurethanes, Resins and Silicones; Gutiérrez, T. J., Ed.; Springer International Publishing: Cham, 2020; pp 65-93.

(55) Ponomarenko, J.; Dizhbite, T.; Lauberts, M.; Volperts, A.; Dobele, G.; Telysheva, G. Analytical pyrolysis - A tool for revealing of lignin structure-antioxidant activity relationship. J. Anal. Appl. Pyrolysis 2015, 113, 360-369.

(56) Ugartondo, V.; Mitjans, M.; Vinardell, M. P. Comparative antioxidant and cytotoxic effects of lignins from different sources. Bioresour. Technol. 2008, 99 (14), 6683-6687.

(57) Li, Z.; Zhang, J.; Qin, L.; Ge, Y. Enhancing Antioxidant Performance of Lignin by Enzymatic Treatment with Laccase. ACS Sustainable Chem. Eng. 2018, 6 (2), 2591-2595.

(58) Kaur, R.; Uppal, S. K.; Sharma, P. Antioxidant and Antibacterial Activities of Sugarcane Bagasse Lignin and Chemically Modified Lignins. Sugar Tech 2017, 19 (6), 675-680.

(59) Sadeghifar, H.; Wells, T.; Le, R. K.; Sadeghifar, F.; Yuan, J. S.; Jonas Ragauskas, A. Fractionation of Organosolv Lignin Using Acetone:Water and Properties of the Obtained Fractions. ACS Sustainable Chem. Eng. 2017, 5 (1), 580-587.

(60) Guo, Z.; Li, D.; You, T.; Zhang, X.; Xu, F.; Zhang, X.; Yang, Y. New Lignin Streams Derived from Heteropoly Acids Enhanced Neutral Deep Eutectic Solvent Fractionation: Toward Structural Elucidation and Antioxidant Performance. ACS Sustainable Chem. Eng. 2020, 8 (32), 12110-12119.

(61) Fox, N. J.; Stachowiak, G. W. Vegetable oil-based lubricants-A review of oxidation. Tribol. Int. 2007, 40 (7), 1035-1046.

(62) Jang, J. Y.; Khonsari, M. M. Lubrication with a Non-Newtonian Fluid. In Encyclopedia of Tribology; Wang, Q. J., Chung, Y.-W., Eds.; Springer US: Boston, MA, 2013; pp 2146-2151.

(63) Daugan, S.; Talini, L.; Herzhaft, B.; Allain, C. Aggregation of particles settling in shear-thinning fluids. Eur. Phys. J. E: Soft Matter Biol. Phys. 2002, 7 (1), 73-81.

(64) Adhvaryu, A.; Biresaw, G.; Sharma, B. K.; Erhan, S. Z. Friction Behavior of Some Seed Oils: Biobased Lubricant Applications. Ind. Eng. Chem. Res. 2006, 45 (10), 3735-3740.
(65) Mu, L.; Ma, X.; Guo, X.; Chen, M.; Ji, T.; Hua, J.; Zhu, J.; Shi, Y. Structural strategies to design bio-ionic liquid: Tuning molecular interaction with lignin for enhanced lubrication. J. Mol. Liq. 2019, 280, 49-57.

(66) Mu, L.; Shi, Y.; Guo, X.; Ji, T.; Chen, L.; Yuan, R.; Brisbin, L.; Wang, H.; Zhu, J. Non-corrosive Green Lubricants: Strengthened Lignin-[Choline][Amino Acid] Ionic Liquids Interaction via Reciprocal Hydrogen Bonding. RSC Adv. 2015, 5, 66067-66072.

(67) Mu, L.; Wu, J.; Matsakas, L.; Chen, M.; Rova, U.; Christakopoulos, P.; Zhu, J.; Shi, Y. Two important factors of selecting lignin as efficient lubricating additives in poly (ethylene glycol): Hydrogen bond and molecular weight. Int. J. Biol. Macromol. 2019, 129, 564-570.

(68) Mu, L.; Wu, J.; Matsakas, L.; Chen, M.; Vahidi, A.; Grahn, M.; Rova, U.; Christakopoulos, P.; Zhu, J.; Shi, Y. Lignin from Hardwood and Softwood Biomass as a Lubricating Additive to Ethylene Glycol. Molecules 2018, 23 (3), 537-547.

(69) McNutt, J.; He, Q. Development of biolubricants from vegetable oils via chemical modification. J. Ind. Eng. Chem. 2016, $36,1-12$.

(70) Ortega-Álvarez, R.; Aguilar-Cortés, G. E.; Hernández-Sierra, M. T.; Aguilera-Camacho, L. D.; García-Miranda, J. S.; Moreno, K. J. Physical and rheological investigation of vegetable oils and their effect as lubricants in mechanical components. MRS Advances 2019, 4 (5960), 3291-3297. 